\title{
Influence of BA and IBA or NAA Combinations on Micropropagation of Cryptolepis sanguinolenta
}

\author{
Maame Adjoa Dwumawa Monney, Naalamle Amissah, Essie Blay \\ Crop Science Department, University of Ghana, Accra, Ghana \\ Email:naalamle@gmail.com
}

Received 29 January 2016; accepted 20 March 2016; published 23 March 2016

Copyright (C) 2016 by authors and Scientific Research Publishing Inc.

This work is licensed under the Creative Commons Attribution International License (CC BY). http://creativecommons.org/licenses/by/4.0/

(c) (i) Open Access

\section{Abstract}

The study being the first of its kind established an efficient protocol for micropropagation of Cryptolepis sanguinolenta, an important endangered medicinal plant species, used in the treatment of Malaria. For shoot induction, semi hard wood nodal segments were maintained on MS (Murashige and Skoog) nutrient medium supplemented with MS vitamins, $30 \mathrm{~g} / \mathrm{L}$ sucrose, $3 \%$ geIrite and various auxin and cytokinin combinations. Treatments involved 6-benzyladenine (BA) at $0.5,1.0,1.5,2.0,2.5$ or $3.0 \mathrm{mg} / \mathrm{L}$ in combination with $0.1 \mathrm{mg} / \mathrm{L}$ Indole 3-butyric acid (IBA) or Naphthaleneacetic acid (NAA). Control consisted of hormone free MS medium. BA and IBA combinations were found to be more efficient in shoot regeneration than the BA and NAA combinations. Cultures maintained on MS medium supplemented with $3 \mathrm{mg} / \mathrm{L} \mathrm{BA}$, in combination with $0.1 \mathrm{mg} / \mathrm{L}$ IBA recorded the highest shoot induction $(100 \%)$, mean shoot length $(1.28 \mathrm{~cm})$ and mean number of nodes per explant (2.5). This, however, did not differ significantly from cultures maintained on 2 or $2.5 \mathrm{mg} / \mathrm{L} \mathrm{BA}$ and $0.1 \mathrm{mg} / \mathrm{L}$ IBA supplemented MS medium. Regenerated shoots were transferred onto different media for root induction. Treatments consisted of full strength MS medium augmented with either 0.5 or $0.1 \mathrm{mg} / \mathrm{L}$ IBA, hormone free half strength MS medium and half strength MS medium augmented with $0.01 \mathrm{mg} / \mathrm{L}$ IBA. After six weeks of culture, no rooting was recorded in all treatments with the exception of half strength MS medium supplemented with 0.01 $\mathrm{mg} / \mathrm{L}$ IBA, which recorded $60 \%$ rooting. Regenerated plantlets were successfully weaned and established in the greenhouse.

\section{Keywords}

C. sanguinolenta, Micropropagation, Plant Growth Regulators 


\section{Introduction}

Cryptolepis sanguinolenta Lindl. Schltr. (syn. Cryptolepis triangularis N. E. Br., or Pergularia sanguinolenta Lindl.), commonly known as "Yellow dye root" or "Ghana quinine”, is an important medicinal plant species belonging to the family Asclepiadaceae/Periplocaceae. Extract from the plant is used in local traditional medicines for the treatment of several diseases, including malaria, jaundice, hepatitis, rheumatism, amoebiasis, urinary and upper respiratory tract infections, stomach and intestinal disorders [1].

Roots of the plant contain the active ingredient cryptolepine which is mostly used in the treatment of malaria. A clinical study of the plant by Boye [2] proved its extracts were as effective as chloroquine when taken orally. Several other minor alkaloids such as hydroquinone, quindoline, cryptoquindoline, cryptoheptine and the 11hydroxy derivatives of cryptolepine, with biological/pharmacological activities have also been found in the roots [1]. This explains the plant's numerous uses in traditional medicine.

As with most medicinal plant species, the raw materials needed for medicinal preparations are mainly obtained from the wild. Cryptolepis sanguinolenta is on the verge of extinction because of the erratic nature of seed germination, seasonal seed production and its destructive mode of harvest (as the roots are the desired plant part for trade). Pressure on wild populations could be reduced if demand is met through more reliable methods of cultivation.

Micropropagation has been conveniently used in the propagation of plant species which have problems with seed germination or do not respond well to vegetative propagation [3]-[5]. However, developing a protocol for micropropagation is affected by the choice, combinations and concentrations of plant growth regulators used [6]. Preliminary studies conducted on this species revealed BA as the most efficient cytokinin for shoot induction and proliferation of semi-hard wood single node cuttings compared to kinetin, zeatin or thidiazuron.

This experiment sought to establish the optimum concentration of BA and auxin combination required for shoot production from stem explants of Cryptolepis sanguinolenta and developed a rooting medium for regenerated shoots.

\section{Materials and Methods}

\subsection{Explant Preparation}

Thirty root cuttings were selected randomly from accessions of Cryptolepis sanguinolenta plants collected from the Ashanti, Eastern, Volta and Brong Ahafo regions of Ghana between July and August 2011. Plants used in the study were identified based on morphological characteristics of the species. Accession and voucher specimen details are as indicated in [7].

Parent plants obtained from the root cuttings were sprayed with $0.3 \%$ systemic fungicide solution (Agriette 80 WP a.i. $800 \mathrm{~g} / \mathrm{kg}$ Fosetyl-AL) about five days prior to the harvest of explants for in vitro culture. Explants were harvested usually about two weeks after cut back. They comprised of semi-hardwood single node cuttings, 1 $1.5 \mathrm{~cm}$ long. Leaves were trimmed off the nodal cuttings and the explants washed with mild detergent (two drops of sunlight washing up liquid), run under water for five minutes and transferred to the laminar flow cabinet. Under the laminar cabinet, the explants were soaked in $20 \%$ bleach (a.i. $6 \% \mathrm{NaOCl}$ ) and gently agitated for 10 minutes. They were subsequently rinsed thoroughly to remove all traces of sterilant with three changes of sterile, triple filtered distilled water.

\subsection{Culture Media Preparation}

For shoot regeneration, cultures were maintained on MS (Murashige and Skoog) basic nutrient medium [8] supplemented with MS vitamins, $30 \mathrm{~g} / \mathrm{L}$ sucrose and BA at 0.5, 1.0, 1.5, 2.0, 2.5 or $3.0 \mathrm{mg} / \mathrm{L}$ in combination with $0.1 \mathrm{mg} / \mathrm{L}$ IBA or NAA. Control consisted of hormone free MS medium. For root induction and subsequent rooting, microshoots, not less than $1 \mathrm{~cm}$ were transferred onto full strength MS medium with vitamins (supplemented with $0.5 \mathrm{mg} / \mathrm{L}$ IBA or $0.1 \mathrm{mg} / \mathrm{L}$ IBA) or half strength MS medium with vitamins (supplemented with $0.01 \mathrm{mg} / \mathrm{L}$ IBA) or hormone freeHalf strength MS medium with vitamins. All media were solidified with $0.3 \%$ gelrite. The $\mathrm{pH}$ was adjusted to $5.7 \pm 0.1$ using $1 \mathrm{~N} \mathrm{NaOH}$ and $1 \mathrm{~N} \mathrm{H}_{2} \mathrm{SO}_{4}$. About $5 \mathrm{ml}$ of media were dispensed into flat bottom polycarbonate culture tubes $(25 \mathrm{~mm} \times 95 \mathrm{~mm}$ ) with polypropylene screw caps (Phyto Technology labs, US) and autoclaved at $121^{\circ} \mathrm{C}$ and $120 \mathrm{kPa}$ for 18 minutes. 


\subsection{Inoculation}

With the aid of sterile, fine, stainless steel scalpel and forceps, the explants were trimmed to about $1 \mathrm{~cm}$ before inoculation. The bases of the explants were inserted vertically into the semi-solid medium. Microshoots not less than $1 \mathrm{~cm}$ were transferred onto rooting media after 8 weeks.

\subsection{Statistical Methods}

Each treatment involved 10 cultures and was replicated three times, in a completely randomized design. Data taken (number of days to shoot induction, percentage shoot induction, shoot length, number of nodes per shoot, number of days to root induction and percentage rooting) were analyzed using analysis of variance with GENSTAT (12 ${ }^{\text {th }}$ edition). Significantly different means were separated using Duncan’s Multiple Range Test.

\section{Results and Discussion}

\subsection{Shoot Induction}

The auxin type played a very important role in shoot induction and proliferation. Generally, BA and IBA combinations were found to be more efficient in shoot regeneration and multiplication of nodal segments of Cryptolepis sanguinolenta than the BA and NAA combinations (Figures 1-3). Benzyladenine (BA) and NAA combinations produced lower percentage shoot inductions and higher mean number of days to shoot induction and lower percentage shoot induction than the control (Table 1).

The combination of BA and NAA was not only inefficient in breaking axillary shoot dormancy, but also had detrimental effects on the cultures. Cultures maintained on NAA supplemented media produced profuse callus, which retarded shoot formation and subsequent shoot growth (Figures 2(e)-(k), Figure 3(l), Figure 3(m)).

Benzyladenine (BA) and IBA combinations proved to be efficient for shoot multiplication in a large number of species belonging to the Asclepiadaceae family [3] [4] [9]-[11]. NAA and BA combinations however, have also been reported to be efficient in some plant species in the Asclepiadaceae family [12] [13].

The number of nodes produced within a period of time gives an estimate of the multiplication rate while shoot height determines the feasibility of subculture. Although the highest mean shoot length $(1.28 \mathrm{~cm})$ was recorded in

Table 1. Effect of BA and IBA/NAA combinations on shoot regeneration from nodal segments of Cryptolepis sanguinolenta in MS medium, 3 Weeks after culture.

\begin{tabular}{|c|c|c|c|c|c|c|}
\hline \multicolumn{3}{|c|}{ Growth regulators (mg/L) } & \multirow{2}{*}{ Shoot induction (\%) } & \multirow{2}{*}{$\begin{array}{l}\text { Mean number of } \\
\text { days to first shoot } \\
\text { induction }\end{array}$} & \multirow{2}{*}{$\begin{array}{l}\text { Mean shoot length } \\
(\mathrm{cm})\end{array}$} & \multirow{2}{*}{$\begin{array}{l}\text { Mean number of } \\
\text { nodes per explants }\end{array}$} \\
\hline BA & IBA & NAA & & & & \\
\hline 0 & 0 & 0 & 95 & $2.3 \pm 0.37^{\text {cba }}$ & $0.98 \pm 0.13^{\mathrm{ab}}$ & $1.6 \pm 0.02^{\mathrm{bc}}$ \\
\hline 0.5 & 0.1 & - & 97 & $1.8 \pm 0.21^{\mathrm{a}}$ & $0.72 \pm 0.18^{\mathrm{bc}}$ & $1.5 \pm 0.22^{\mathrm{bc}}$ \\
\hline 1.0 & 0.1 & - & 100 & $1.9 \pm 0.20^{\text {ba }}$ & $0.74 \pm 0.05^{\mathrm{bc}}$ & $1.5 \pm 0.05^{\mathrm{bc}}$ \\
\hline 1.5 & 0.1 & - & 97 & $1.8 \pm 0.29^{\mathrm{a}}$ & $0.91 \pm 0.17^{\mathrm{ab}}$ & $1.6 \pm 0.10^{\mathrm{bc}}$ \\
\hline 2.0 & 0.1 & - & 93 & $1.8 \pm 0.04^{\mathrm{a}}$ & $0.98 \pm 0.14^{\mathrm{ab}}$ & $1.9 \pm 0.21^{\mathrm{abc}}$ \\
\hline 2.5 & 0.1 & - & 97 & $1.5 \pm 0.10^{\mathrm{a}}$ & $1.07 \pm 0.21^{\mathrm{ab}}$ & $2.1 \pm 0.28^{\mathrm{ab}}$ \\
\hline 3.0 & 0.1 & - & 100 & $1.5 \pm 0.20^{\mathrm{a}}$ & $1.28 \pm 0.22^{\mathrm{a}}$ & $2.1 \pm 0.24^{\mathrm{a}}$ \\
\hline 0.5 & - & 0.1 & 77 & $3.5 \pm 0.29^{\mathrm{dc}}$ & $0.27 \pm 0.04^{\mathrm{c}}$ & $1.0 \pm 0.00^{c}$ \\
\hline 1.0 & - & 0.1 & 86 & $3.2 \pm 0.23^{\mathrm{dcb}}$ & $0.24 \pm 0.01^{\mathrm{c}}$ & $1.0 \pm 0.00^{c}$ \\
\hline 1.5 & - & 0.1 & 77 & $3.4 \pm 0.28^{\mathrm{dc}}$ & $0.27 \pm 0.06^{\mathrm{c}}$ & $1.0 \pm 0.00^{c}$ \\
\hline 2.0 & - & 0.1 & 80 & $2.8 \pm 0.13^{\mathrm{dcba}}$ & $0.27 \pm 0.06^{\mathrm{c}}$ & $1.3 \pm 0.14^{\mathrm{c}}$ \\
\hline 2.5 & - & 0.1 & 78 & $3.4 \pm 0.49^{\mathrm{dc}}$ & $0.28 \pm 0.06^{\mathrm{c}}$ & $1.0 \pm 0.00^{\mathrm{c}}$ \\
\hline 3.0 & - & 0.1 & 89 & $3.7 \pm 0.67^{\mathrm{d}}$ & $0.27 \pm 0.04^{\mathrm{c}}$ & $1.0 \pm 0.00^{c}$ \\
\hline
\end{tabular}

Values represent means \pm se. Any two means not followed by one or more letters in common within a column are significantly different at $\mathrm{p}<0.05$ according to Duncan's Multiple Range Test. 


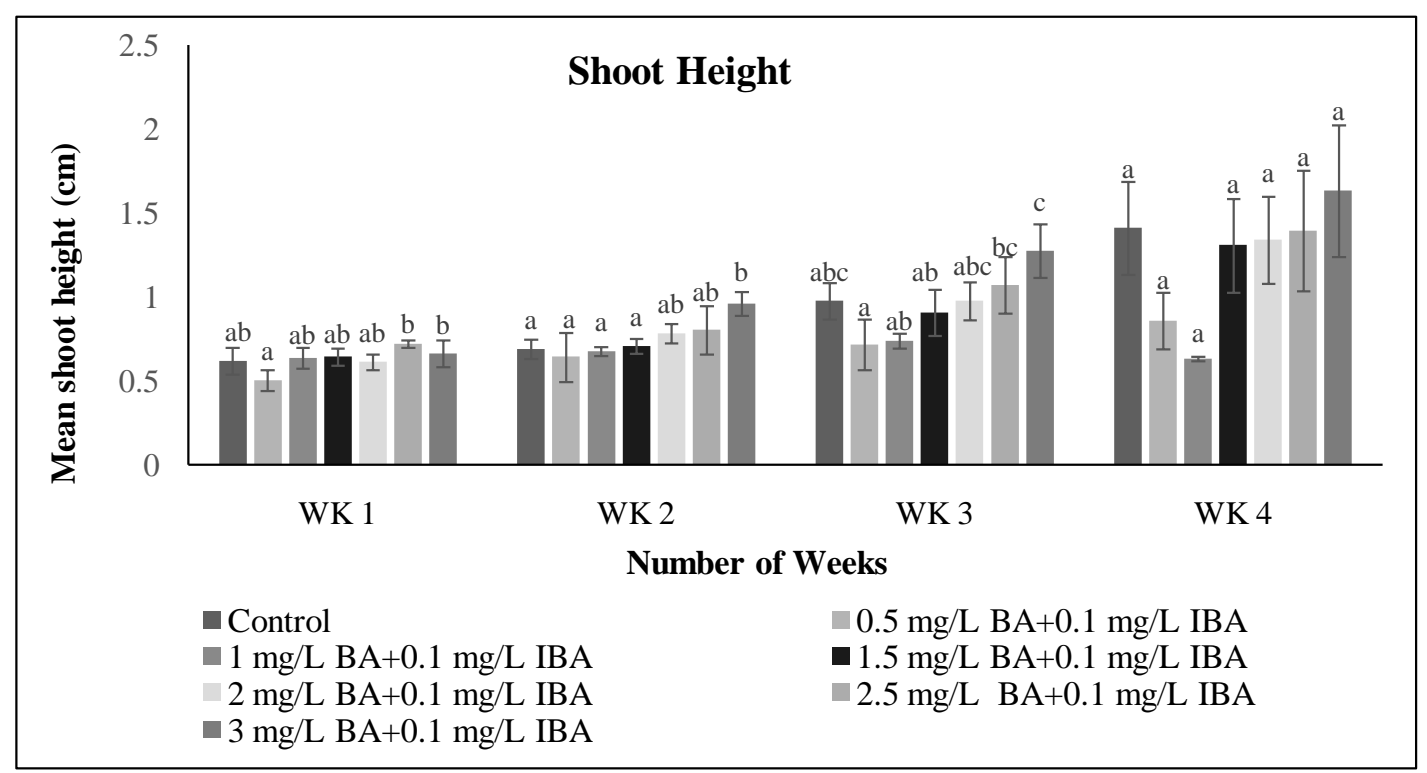

(a)

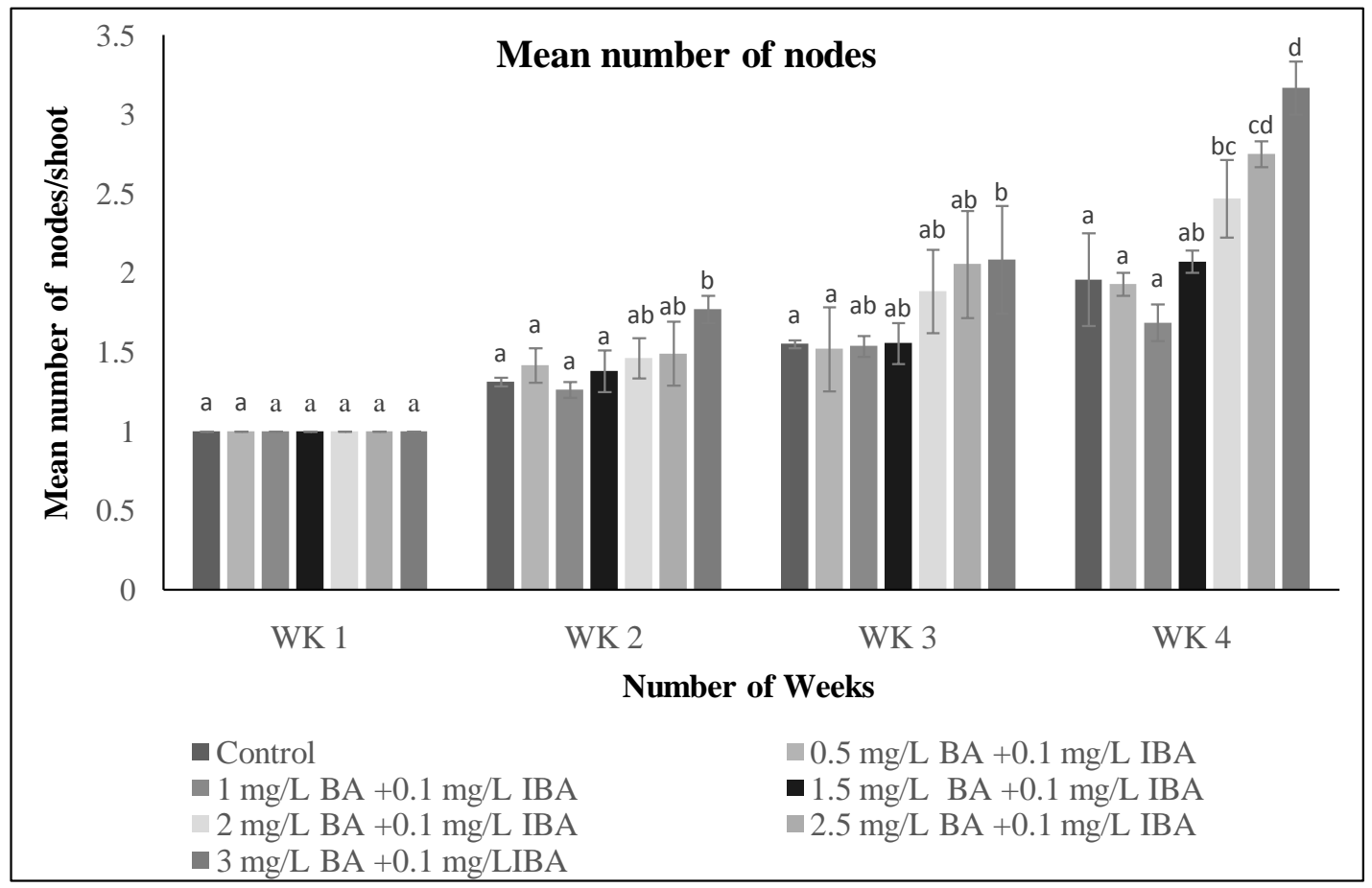

(b)

Figure 1. Effect of BA at different concentrations, in combination with IBA on growth rate of in vitro proliferated shoots from nodal segments of Cryptolepis sanguinolenta 4 Weeks after culture. Mean shoot height (a); mean number of nodes per explant (b). Any two means not followed by one or more letters in common within a week are significantly different at $\mathrm{p}<0.05$ according to Duncan's multiple range test.

cultures maintained on MS medium supplemented with $3.0 \mathrm{mg} / \mathrm{L} \mathrm{BA}$ (in combination with $0.1 \mathrm{mg} / \mathrm{L} \mathrm{IBA}$ ), it did not differ significantly from cultures maintained on the other high BA concentrations $(1.5,2.0,2.5 \mathrm{mg} / \mathrm{L})$ and $0.1 \mathrm{mg} / \mathrm{L}$ IBA supplemented media and also the control (Table 1). However, it was significantly higher than mean shoot lengths recorded in the low BA concentrations ( 0.5 and $1.0 \mathrm{mg} / \mathrm{L} \mathrm{BA}$ ) and $0.1 \mathrm{mg} / \mathrm{L} \mathrm{IBA}$ (Table 1$)$. The efficacy of plant growth regulator is dependent on its concentration [14]-[17]. 


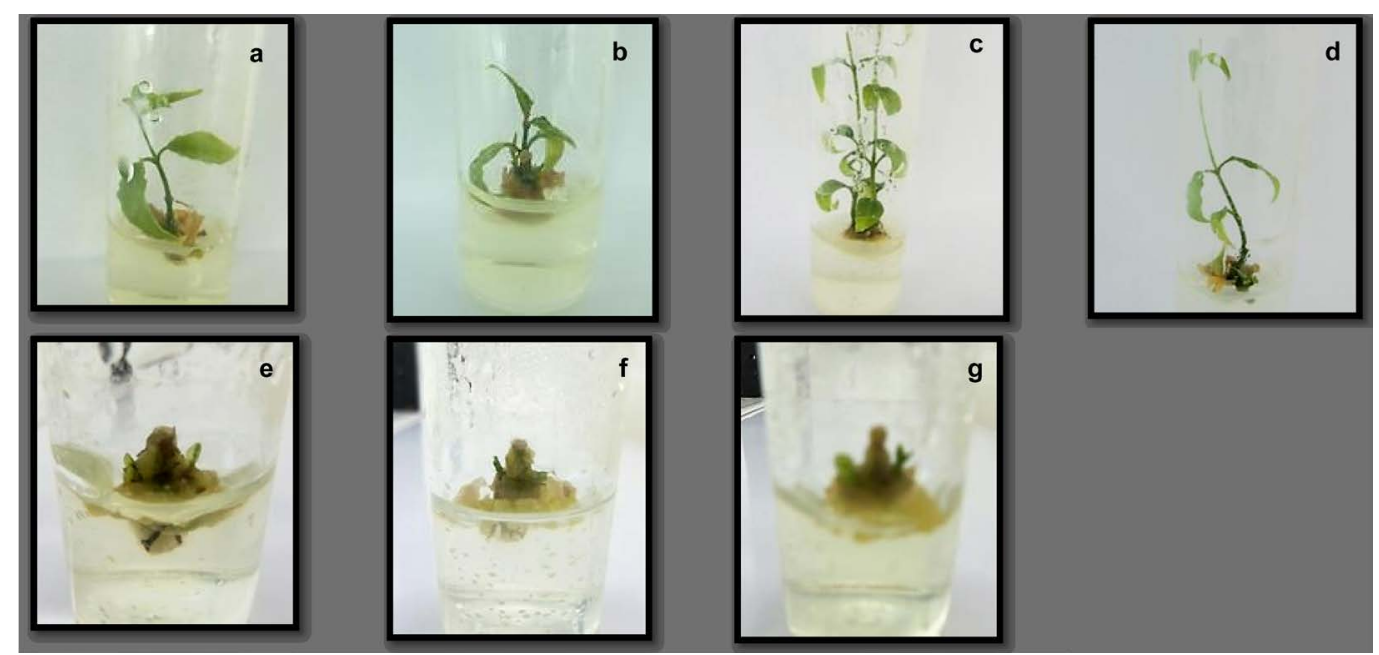

Figure 2. Response of nodal segments of Cryptolepis sanguinolenta to different BA concentrations and different auxin combinations 3 weeks after culture. Shoot induction on $0.5 \mathrm{mg} / \mathrm{L} \mathrm{BA}+0.1 \mathrm{mg} / \mathrm{L} \mathrm{IBA} \mathrm{(a);} 1.0$ $\mathrm{mg} / \mathrm{L} \mathrm{BA}+0.1 \mathrm{mg} / \mathrm{L} \mathrm{IBA} \mathrm{(b);} 1.5 \mathrm{mg} / \mathrm{L} \mathrm{BA}+0.1 \mathrm{mg} / \mathrm{L} \mathrm{IBA} \mathrm{(c);} \mathrm{Control} \mathrm{(d);} 0.5 \mathrm{mg} / \mathrm{L} \mathrm{BA}+0.1 \mathrm{mg} / \mathrm{L}$ NAA (e); $1.0 \mathrm{mg} / \mathrm{L} \mathrm{BA}+0.1 \mathrm{mg} / \mathrm{L}$ NAA (f);1.5 mg/L BA + $0.1 \mathrm{mg} / \mathrm{L} \mathrm{NAA}$ (g).

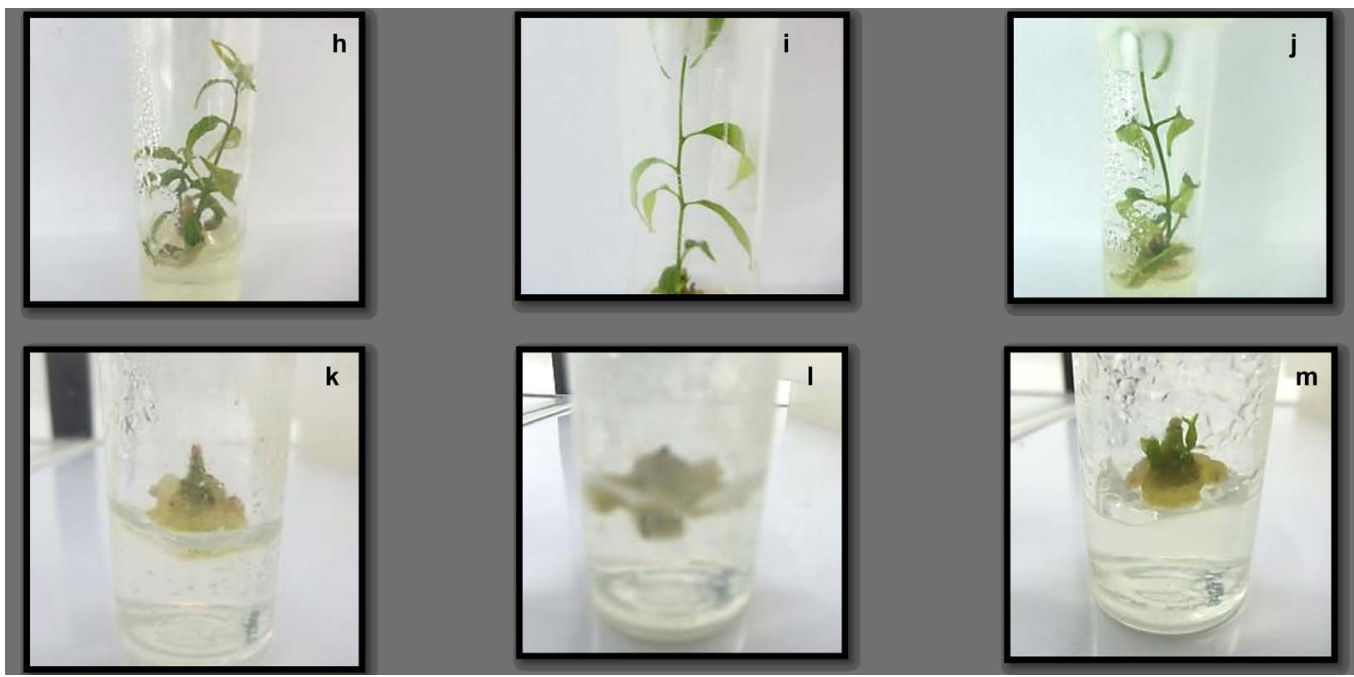

Figure 3. Response of nodal segments of Cryptolepis sanguinolenta to different BA concentrations and different auxin combinations 3 weeks after culture. Shoot induction on $2.0 \mathrm{mg} / \mathrm{L} \mathrm{BA}+0.1 \mathrm{mg} / \mathrm{L} \mathrm{IBA}(\mathrm{h}) ; 2.5$ $\mathrm{mg} / \mathrm{L} \mathrm{BA}+0.1 \mathrm{mg} / \mathrm{L}$ IBA (i); $3.0 \mathrm{mg} / \mathrm{L} \mathrm{BA}+0.1 \mathrm{mg} / \mathrm{L} \mathrm{IBA} \mathrm{(j);} 2.0 \mathrm{mg} / \mathrm{L} \mathrm{BA}+0.1 \mathrm{mg} / \mathrm{L} \mathrm{NAA}(\mathrm{k}) ; 2.5$ $\mathrm{mg} / \mathrm{L} \mathrm{BA}+0.1 \mathrm{mg} / \mathrm{L} \mathrm{NAA}(\mathrm{l}) ; 3.0 \mathrm{mg} / \mathrm{L} \mathrm{BA}+0.1 \mathrm{mg} / \mathrm{L} \mathrm{NAA}(\mathrm{m})$.

High shoot length recorded in the control suggests the presence of endogenous auxins which may have induced shoot elongation [18]. In addition to increased shoot length, the number of nodes was significantly improved by BA, proving its ability to enhance axillary bud development in Cryptolepis sanguinolenta.

\subsection{Root Induction}

Some species may root readily even in the course of multiplication, while others may require the inclusion of auxin in the medium. According to Sathyanarayana and Varghese [19], transfer onto auxin supplemented medium becomes necessary if rooting is not observed after two monthly passages on the basal nutrient medium. Other species may also root when simply transferred onto a hormone free medium [14] [15].

Cultures transferred onto hormone free half strength medium, began to form callus at the base [first sign of rooting; Figure 4(b)] by the fourth week after transfer. However, no rooting was observed by the sixth week 
(Table 2; Figure 5(c)).

Cultures transferred onto full strength MS medium, supplemented with $0.5 \mathrm{mg} / \mathrm{L}$ IBA, exhibited the highest

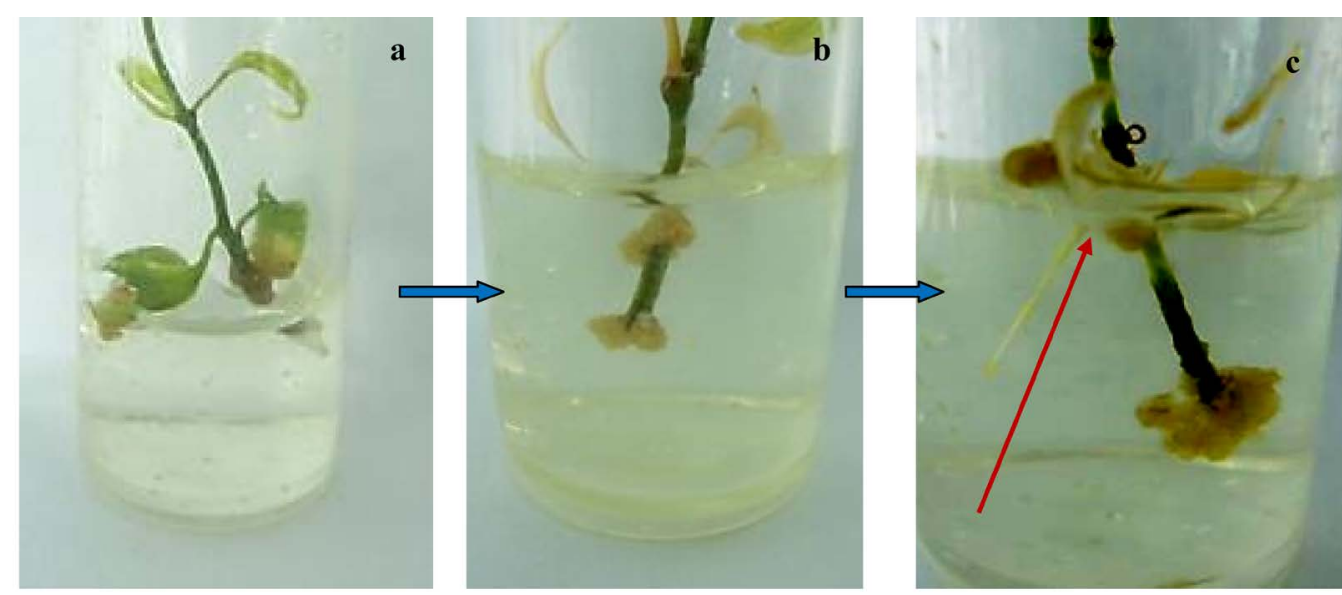

Figure 4. Phases of root induction in Cryptolepis sanguinolenta. Inoculation of microshoot into rooting media (a); appearance of callus (b); emergence of root from callus (red arrow pointing to root) (c).

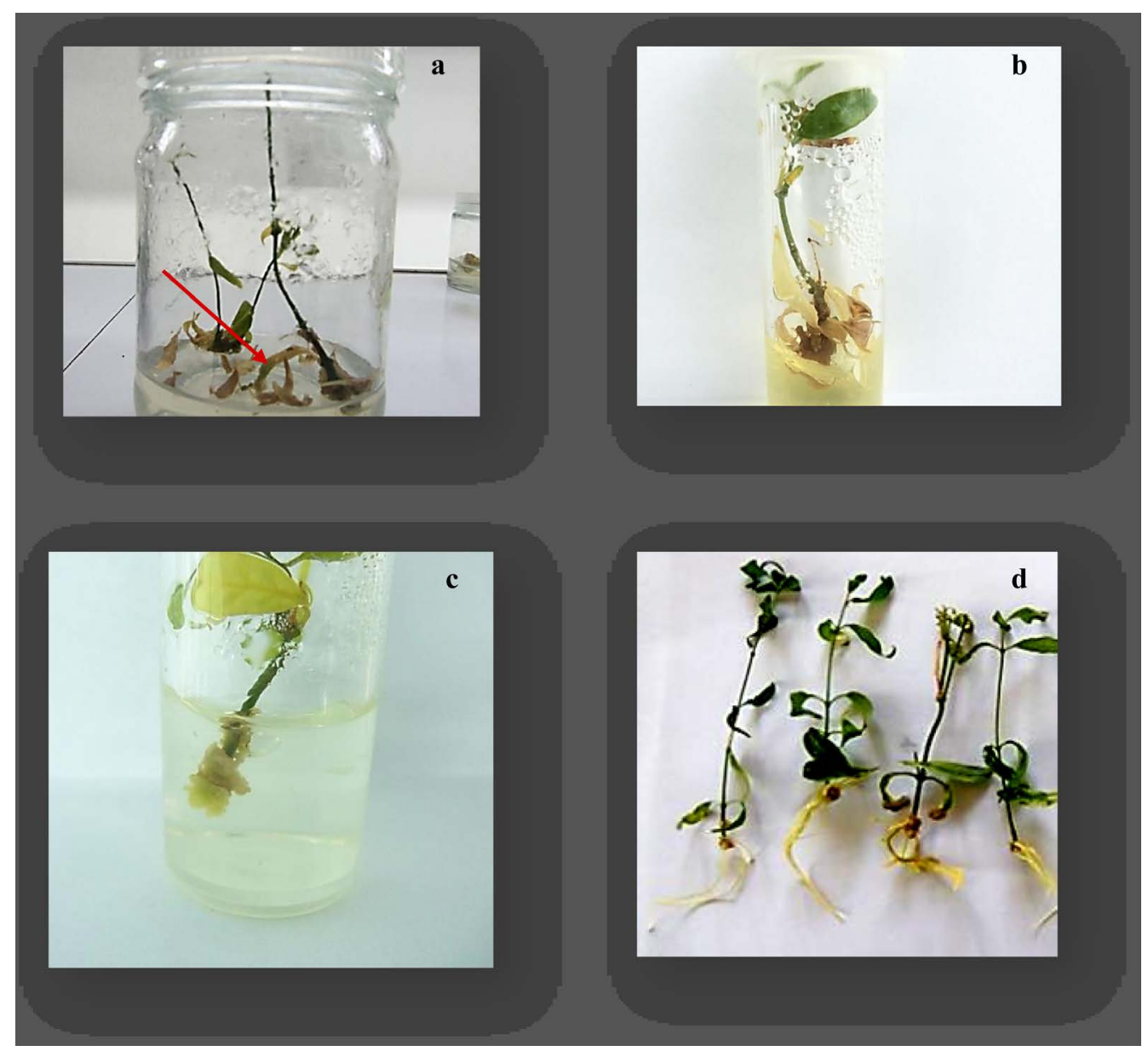

Figure 5. Microshoots of Cryptolepis sanguinolenta in different root induction media 6 WAC. Leaf drop in microshoots on full strength MS + $0.5 \mathrm{mg} / \mathrm{LIBA}$ (Red arrow pointing to leaves) (a); microshoot on full strength MS + $0.1 \mathrm{mg} / \mathrm{L} \mathrm{IBA} \mathrm{(b);} \mathrm{callus} \mathrm{induction} \mathrm{in} \mathrm{microshoot} \mathrm{on} 1 / 2$ strength MS (c); rooting in microshoots obtained from $1 / 2$ strength MS $+0.01 \mathrm{mg} / \mathrm{L}$ IBA (d). 
level of stress. Leaves of cultures began to drop after 24 hours of transfer and within the first week, almost all the cultures shed off their leaves and began to show signs of scorching (Figure 5(a)). No signs of rooting were observed even after the six weeks of transfer (Table 2). Reducing IBA concentration to $0.1 \mathrm{mg} / \mathrm{L}$ reduced the extent of necrosis (Figure 5(b)).

Cultures transferred onto half strength MS medium supplemented with $0.01 \mathrm{mg} / \mathrm{L}$ IBA began to form callus at the base by the second week, and by the sixth week all cultures had formed callus with about $60 \%$ rooting (Table (2) \& Figure 5(d)).

Rooting of cultures in half strength MS basal medium has been successful in a number of species belonging to the Asclepiadaceae family [11] [12].

It was observed that roots developed by microshoots previously maintained on hormone supplemented media (BA in combination with IBA) were thicker, deep yellow in colour and had more lateral roots than roots developed by microshoots raised on hormone free medium (Figure 6).

\section{Conclusion}

A combination of single node segments of semi-hard wood explants of Cryptolepis sanguinolenta and MS medium supplemented with $2 \mathrm{mg} / \mathrm{L} \mathrm{BA}$ and $0.1 \mathrm{mg} / \mathrm{L} \mathrm{IBA}$ for shoot induction and rooting on 1/2 strength MS medium supplemented with $0.01 \mathrm{mg} / \mathrm{L}$ IBA provided an efficient protocol for micropropagation of Cryptolepis sanguinolenta.

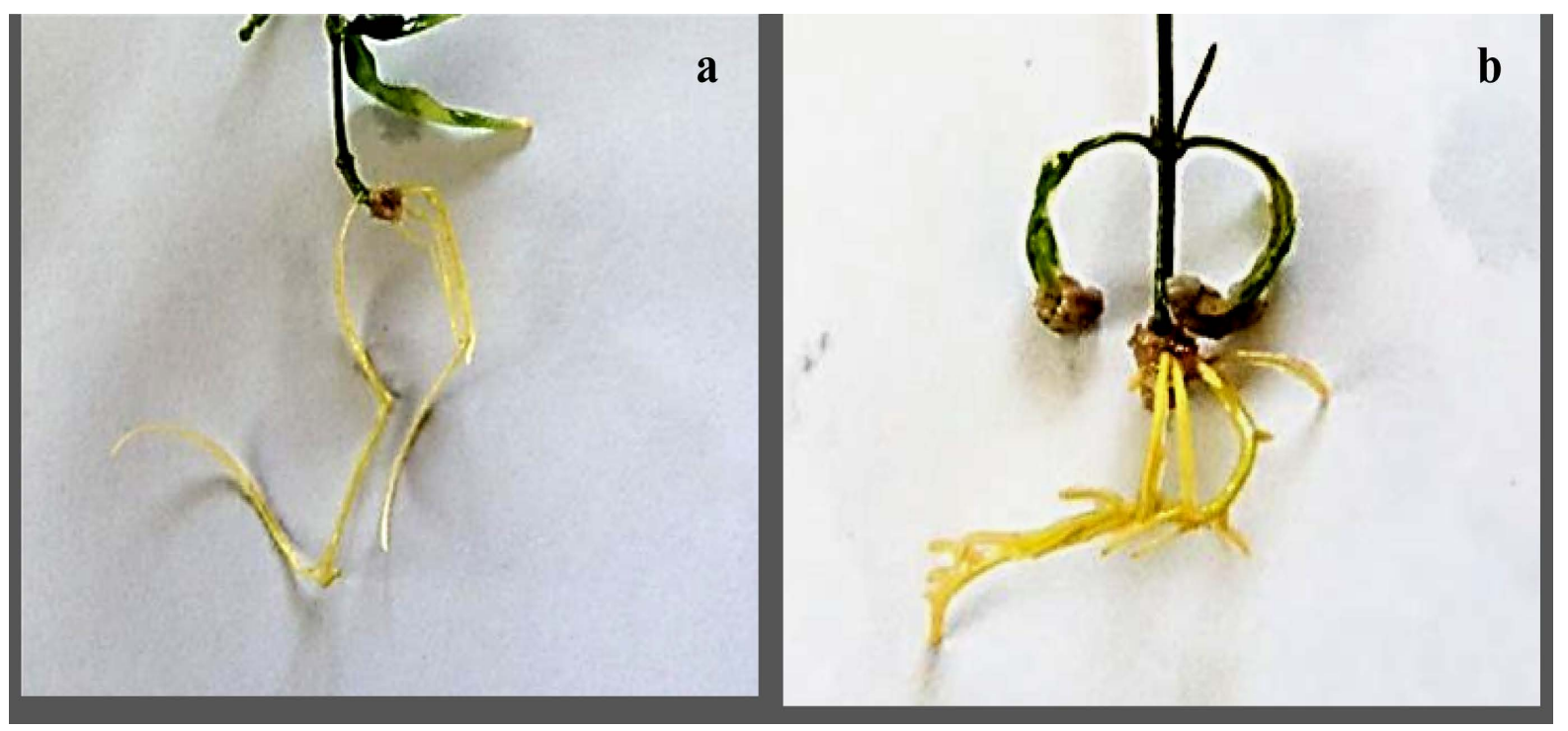

Figure 6. Morphological differences in rooting of microshoots previously maintained on MS medium supplemented with or without hormone (BA + IBA). Thin cream coloured roots produced by microshoot generated on hormone free MS medium (a); thick deep yellow roots with lateral roots produced by microshoot generated onhormone supplemented medium (BA + IBA) (b).

Table 2. Effect of different MS basal strengths and IBA combinations on rooting of microshoots of Cryptolepis sanguinolenta.

\begin{tabular}{ccc}
\hline Treatment & $\begin{array}{c}\text { Number of days to first root } \\
\text { induction }\end{array}$ & Percentage rooting \\
\hline Full strength MS medium $+0.5 \mathrm{mg} / \mathrm{L} \mathrm{IBA}$ & - & 0 \\
Full strength MS medium $+0.1 \mathrm{mg} / \mathrm{L} \mathrm{IBA}$ & - & 0 \\
Half strength MS medium & - & 0 \\
\hline Half strength MS medium $+0.01 \mathrm{mg} / \mathrm{L} \mathrm{IBA}$ & $\mathbf{2 1}$ & $\mathbf{6 0}$ \\
\hline
\end{tabular}




\section{Acknowledgements}

The authors are grateful to the Volkswagen Stiftung Foundation of Germany for providing the funds used in carrying out this research. The authors would also like to appreciate Professor Samuel Sackey for the use of his tissue culture laboratory and technical support.

\section{Conflict of Interest}

The authors (M. A. D. Monney, N. Amissah and E. Blay) declare that they have no conflict of interest.

\section{Authors' Contribution}

N. Amissah conceived research. N. Amissah and E. Blay supervised research. M. A. D. Monney and E. Blay designed research. M. A. D. Monney conducted experiment and analyzed data. All authors read and approved the manuscript.

\section{References}

[1] Kruidwis (2011) Kruidwis Descriptor. https://sites.google.com/site/kruidwis/planten-van-a-tot-z/cryptolepis

[2] Boye, G.L. (1989) Studies on Antimalarial Action of Cryptolepis sanguinolenta Extract. Proceedings of the International Symposium on East-West Medicine, Seoul, 10-11 October 1989, 243-251

[3] Martin, K.P. (2002) Rapid Propagation of Holostemma ada-kodien Schult., a Rare Medicinal Plant, through Axillary Bud Multiplication and Indirect Organogenesis. Plant Cell Reports, 21, 112-117. http://dx.doi.org/10.1007/s00299-002-0483-7

[4] Chakradhar, T. and Pullaiah, T. (2006) Effect of Explant Source on Axillary Shoot Multiplication during Micropropagation of a Rare Medicinal Plant—Wakatta volubilis (L f). Stapf. Journal of Plant Biochemistry and Biotechnology, 15, 43-45. http://dx.doi.org/10.1007/BF03321900

[5] Faisal, M., Ahmad, N. and Anis, M. (2007) An Efficient Micropropagation System for Tylophora indica: An Endangered, Medicinally Important Plant. Plant Biotechnology Reports, 1, 155-161.

[6] Dodds, J.H. and Roberts, L.W. (1995) Experiments in Plant Tissue Culture. Press Syndicate of the University of Cambridge, Melbourne.

[7] Amissah, J.N., Spiller, M., Oppong, A., Osei-Safo, D., Owusu-Darko, R., Debener, T., Danquah, E.Y. and AddaeMensah, I. (2016) Genetic Diversity and Cryptolepine Concentration of Cryptolepis sanguinolenta (Lindl). Schlt. from Selected Regions of Ghana. Journal of Applied Research on Medicinal and Aromatic Plants, 3, 34-41. http://dx.doi.org/10.1016/j.jarmap.2015.12.005

[8] Murashige, T. and Skoog, F. (1962) A Revised Medium for Rapid Bioassays with Tobacco Tissue Cultures. Physiologia Plantarum, 15, 473-497. http://dx.doi.org/10.1111/j.1399-3054.1962.tb08052.x

[9] Martin, K.P. (2003) Plant Regeneration through Somatic Embryogenesis on Holostemma ada-kodien, a Rare Medicinal Plant. Plant Cell Tissue and Organ Culture, 72, 79-82. http://dx.doi.org/10.1023/A:1021229422172

[10] Beena, M.R., Martin, K.P., Kirtil, P.B. and Hariharan, M. (2003) Rapid in Vitro Propagation of Medicinally Important Ceropegia candelabrum. Plant Cell, Tissue and Organ Culture, 72, 285-289. http://dx.doi.org/10.1023/A:1022395809204

[11] Arulanandam, L.P.J., Kumar, S.G. and Sawmini, M. (2011) Micropropagation and Conservation of Rare Medicinal Plant Wakatta volubilis (Linn.) Stapf. Indian Journal of Biotechnology, 10, 238-241.

[12] Sudha, C.G., Krishnan, P.N. and Pushpangadan, P. (1998) In Vitro Propagation of Holostemma annulare (Roxb.) K. Schum., a Rare Medicinal Plant. In Vitro Cellular and Developmental Biology Plant, 34, 57-63. http://dx.doi.org/10.1007/BF02823124

[13] Vinothkumar, D., Murugavelh, S. and Senthilkumar, M. (2011) Clonal Propagation of Wakatta volubilis through Nodal Explants Culture. Ceylon Journal of Science (Biological Sciences), 40, 53-58. http://dx.doi.org/10.4038/cjsbs.v40i1.3406

[14] Nunes, E.C., Volkmer, C.C., Moreno, F.N. and Viana, A.M. (2002) In Vitro Culture of Cedrela fissilis Vellozo (Meliaceae). Plant Cell, Tissue and Organ Culture, 70, 259-268. http://dx.doi.org/10.1023/A:1016509415222

[15] Beegum, S.A., Martin, P.K., Zang, C., Nishita, J.K., Ligimol, Slater, A. and Madhusodanan, P.V. (2007) Organogenesis from Leaf and Internode Explants of Ophiorrhia prostrate, an Anticancer Drug (Camptothecin) Producing Plant. Electronic Journal of Biotechnology, 10, 115-123. http://dx.doi.org/10.2225/vol10-issue1-fulltext-7 
[16] Jamaleddine, Z.O., Lyam, P., Fajimi, O., Giwa, A., Tina, A., Lawyer, E.F., Okere, A.U. and Odofin, W.T. (2011) In Vitro Growth Response of Artemisia annua Seeds to Different Concentrations of Plant Growth Regulators. African Journal of Biotechnology, 10, 17841-17844. http://dx.doi.org/10.5897/ajb10.1289

[17] Demeke, Y., Tefera, W., Dechassa, N. and Abebie, B. (2014) Effects of Plant Growth Regulators on in Vitro Cultured Nodal Explants of Cassava (Manihot esculenta Crantz) Clones. African Journal of Biotechnology, 13, 2830-2839. http://dx.doi.org/10.5897/AJB2013.13287

[18] Phyto Technology Laboratories (2011) Plant Growth Regulators. http://www.phytotechlab.com

[19] Sathyanarayana, B.N. and Varghese, D.B. (2007) Plant Tissue Culture; Practices and New Experimental Protocols. I. K. International Publishing Hse. Pvt. Ltd., New Delhi. 